\title{
Reconnaissance GPR investigation of the ice caps on islands of Wilhelm Archipelago and on Berthelot island (West Antarctica)
}

\author{
A. Chernovi', A. Ivko ${ }^{2}$, O. Bulakh ${ }^{2}, 2021$ \\ ${ }^{1}$ National Antarctic Scientific Center of Ukraine, Kyiv, Ukraine \\ ${ }^{2}$ Institute of Geology, Taras Shevchenko National University of Kyiv, Kyiv, Ukraine
}

Received 1 November 2021

\begin{abstract}
In this paper results of Antarctic ice caps investigations with Ground penetrating radar (GPR) are represented. Local glaciological investigations of small glaciers on islands at the western coast of the AP are rare. Ice thickness is an important parameter for ice mass balance calculation. Investigation of the layering help to reveal information about past climate conditions and to understand glacio-geological history of the region. However, neither the information about the thickness nor interior structure of the ice caps on represented islands are contained in modern database Global Terrestrial Network for Glaciers. The research is aimed at investigating the thickness and interior structure of the ice caps on Antarctic islands Pléneau, Petermann, Booth, Berthelot, Stego and Elisabethinsel. This territory was described only on the level of pioneering research in 19-20th centuries. The aim of the research is to obtain data about the general structure of the ice caps and ice thickness. VIY 3-300 (300 MHz) was applied to the surveying. Processed GPR profiles show up to 14 layers (Pléneau island) inside the ice caps. There are interior crevasses, zones of moisture concentration and voids. Maps of the ice thickness were built for each island. The ice thickness on Stego and Elisabethinsel, Booth and part of Pléneau islands is more than $27 \mathrm{~m}$, so it is recommended to use less frequency of the antennae than 300 $\mathrm{MHz}$ for a deeper and more detailed research of these ice caps. There are crevasses inside the ice near the surface, so for further investigations it is better to use special equipment to prevent any emergency situations (ropes, crampons, ice-hammerd, etc.). Landing sites on the islands with better access to the territories are mentioned in this paper.
\end{abstract}

Key words: ice caps, glaciers, Antarctica, ground penetrating radar, interior structure.

Introduction. Glaciers across the Antarctic Peninsula (AP) are very sensitive and respond directly to climate change [Rau et al., 2004]. A general retreat of glaciers around the AP has been observed since 1975 [Cook et al., 2016]. However, local glaciological investigations of small glaciers on islands at the western coast of the AP are rare [Rundle, 1973]. Surveys on the ice ramp at Rothera Point on Adelaide Island suggest receding since 1989 [Smith et al., 1998] and it is concluded that there is a substantial difference between sites located even very small distances apart and at similar elevations, because the local nature of meteorological conditions largely results from local topography.
Our research is aimed at investigating of ice thickness and interior structure of ice caps on Antarctic islands Pléneau, Petermann, Booth, Berthelot, and Dannebrog islands. Ice thickness is an important parameter for ice mass balance calculation. Structure of the ice help to reveal information about past climate conditions and to understand the glacio-geological history of the region [Lüthi et al., 2008]. Internal reflecting horizons (IRHs) represent isochronous layers that may be identified by ice radar (or ground penetrating radar) and traced for hundreds of kilometers. These IRHs are formed as a result of systematic vertical variations in ice permittivity, mainly due to changes in the impuri- 
ty content of the ice and, to a lesser extent, its density and crystallography [Bryn, 2005] . Authors of the paper [Siegert et al., 1998] applied this approach to extend the chrono-stratigraphy of the Vostok ice core to a potential drill site near Dome C, located $200 \mathrm{~km}$ away. However, neither the information about the thickness nor interior structure of the ice caps on represented islands are contained in modern database Global Terrestrial Network for Glaciers.

The reflection from potential water surface was identified on Uruguay Island (Argentine Islands) during the Ukrainian-Latvian expedition in 2018. Anomaly from the water surface on Uruguay Island was mapped more precisely during a Ukrainian seasonal expedition, drilling confirmed the presence of water under $12 \mathrm{~m}$ of ice in 2020 and biological organisms were found in the freshwater subglacial lake [Chernov et al., 2020a]. Therefore, potentially on other islands of this region there can also be subglacial lakes, which are among the topics of high scientific interest of the scientists around the globe.

In the publication [Karušs et al., 2019] it is concluded, that GPR gives reliable information about ice thickness of the ice caps (with a mistake of thickness measurement $40-72$ $\mathrm{cm})$, area and volume of the ice caps on Argentine Islands is described.

There are several topics which claim scientific interest for the research in this region: lack of profound glaciological investigations, discovery of subglacial lakes, unknown information about thickness and interior structure of glaciers.

The aim of the research is to gather data on the general structure of the ice caps and the ice thickness. We present results of the investigation from Dannebrogs, Booth, Pléneau, Petermann, and Berthelot Islands.

History of investigations. The first research on Pléneau, Petermann, Booth, Berthelot and Dannebrog islands began when glaciology was separated as ascientific direction and when the first studies of the Antarctic Peninsula West Coast were organized. In particular, it was here that the famous Polish polar explorer H. Arctowski began his work as part of the
Belgian Antarctic Expedition (BelgAE) on the ship «Belgica» in 1897-1899, summarizing his observations in the work [Arctowski, 1904]. The expedition carried out the first polar wintering, and observed the annual cycle of natural processes in Antarctica. H. Arctowski observed fluctuations in the level of glacial cover and associated it with climate change, described the movement of solid ice, the destructive work of the glaciers. In 1903-1905 E. Gourdon carried out glaciological research as part of the French Antarctic Expedition (FrAE) of J. Charcot. During the fourth French expedition, the ship "Pourquoi-Pas?» moored on the Petermann Island. Topographical survey was carried out, samples of the ice were taken, glaciological features of the territory were described [Gourdon, 1908].

During these expeditions, most of the islands with the objects of our research (Fig. 1) were discovered and named after prominent personalities. Further information about islands location and their features comes from "Antarctica: an encyclopedia» [Stewart, 2011].

Dannebrog Islands. $65^{\circ} 03^{\prime} \mathrm{S}, 64^{\circ} 08^{\prime} \mathrm{W}$. Agroup of islands and rocks, including Rollet Island and Elisabethinsel, between the Wauwermans Islands and the Vedel islands, in the Wilhelm Archipelago. During BelgAE 1897-99 de Gerlache named them Îles Dannebrog.

Booth Island. $65^{\circ} 05^{\prime} \mathrm{S}, 64^{\circ} 00^{\prime} \mathrm{W}$. Y-shaped island, between 6 and $8 \mathrm{~km}$ long, and $6 \mathrm{~km}$ wide at its broadest, separated from the Graham Coast of Graham Land by the Lemaire Channel, in the NE part of the Wilhelm Archipelago. Dallmann discovered it in January 1874, and named it Booth-Insel (or Boothinsel) for Oskar and Stanley Booth, members of the Hamburg Geographical Society, which had sent out the expedition.

Pléneau Island. $65^{\circ} 06^{\prime} \mathrm{S}, 64^{\circ} 04^{\prime} \mathrm{W}$. An island, about $1.4 \mathrm{~km}$ long, just NE of Hovgaard Island, in the Wilhelm Archipelago, off the Graham Coast, on the W coast of Graham Land. The NE point of this island was charted by FrAE 1903-05, and named by Charcot as Pointe Pléneau, for Paul Pléneau, expedition's photographer.

Petermann Island. $65^{\circ} 10^{\prime} \mathrm{S}, 64^{\circ} 10^{\prime} \mathrm{W}$. An island, $1.5 \mathrm{~km}$ long, and $1 \mathrm{~km}$ wide at its broad- 


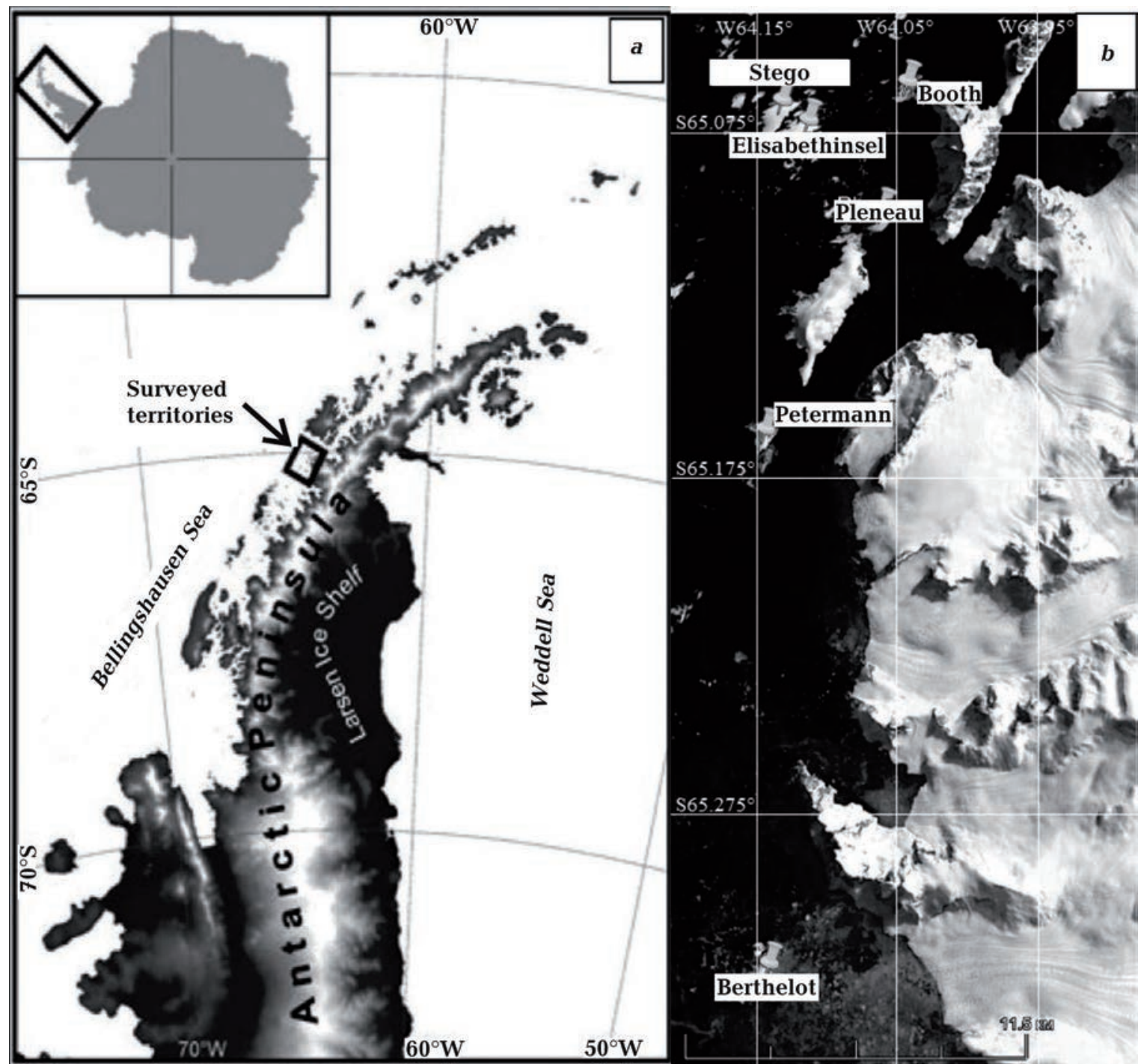

Fig. 1. Location of surveyed territories on the map of Antarctic Peninsula, prepared using the Scientific Committee on Antarctic Research Antarctic Digital Database (ADD) (a) and marking of separate islands $(b)$.

est, $1.5 \mathrm{~km}$ SW of Hovgaard Island, on the W side of Penola Strait, between Hovgaard Island and the Argentine Islands, in the Wilhelm Archipelago, off the Graham Coast, on the W coast of the Antarctic Peninsula. Discovered by Dallmann in 1873-74, and named by him as Petermann-Insel (i. e., «Petermann Island»), for August Heinrich Petermann (1822-1878), the German geographer.

Berthelot Islands. $65^{\circ} 20^{\prime} \mathrm{S}, 64^{\circ} 09^{\prime} \mathrm{W}$. Agroup of islands, consisting of one main island (Berthelot Island), $1.5 \mathrm{~km}$ long and rising to an elevation of $165 \mathrm{~m}$ above sea level, and surro- unded by little islands and rocks (the main one of these being the most northerly, Green Island), off the W coast of Graham Land. Discovered by FrAE 1904, roughly charted by them as one island, which Charcot named Île Berthelot, for Marcelin-Pierre-Eugène Berthelot (1827-1907), prominent French chemist and politician [Stewart, 2011].

In the work [Adie, 1957] investigations of Graham Land petrography and description of gabbro and granites of the region are represented. [Curtis, 1966] describes petrography of the Graham Coast, several Wilhelm Archi- 
pelago islands, in particular Petermann Island. There are a lot of maps, geological cross-section review. The most recent studies of the geological history of this region was done by Ukrainian scientists. In the work [Mitrokhin et al., 2018] authors described granitoid intrusions, gabbro and diabase to determine the geological history on Petermann Island. Mentioned papers do not include information about glaciology of the region. There is no exact point of view about the origin of the ice caps in this region. The abovementioned surveys in the $20^{\text {th }}$ century were pioneering and describe general features of the islands but not much attention was paid to the glaciological studies of ice caps.

During British Antarctic Expeditions, first glaciological observations were focused on ice surface topography and carried out on Galindez Island (one of Argentine Islands, 10-20 km away from the research objects of this paper) [Fleming et al., 1938; Thomas, 1963; Sadler, 1968]. During Ukrainian expeditions, detailed investigations of glaciers interior with electromagnetic methods were done. Ground penetrating radar and vertical electrical resonance sounding methods were used to measure the thickness of the Galindez Island ice cap [Levashov et al., 2004; Bakhmutov et al., 2006]. Monitoring of the frontal parts of the ice caps on Galindez and Winter Islands was started in 2002 using the photogrammetric method [Glotov et al., 2003; Cisak et al., 2008; Tretyak et al., 2016].

Monitoring of the ice caps interior on Argentine Islands with ground penetrating radar (GPR) has been organized since May 2017 [Chernov, 2017]. Comprehensive ice thickness mapping and investigation of glaciers' structure is successfully done with the GPR method on Argentine Islands [Chernov, 2017; Chernov et al., 2018, 2020b; Karušs et al., 2019].

All mentioned technics of the research fullfill information about the ice caps and give information about glaciers' surface, interior structure, volume of the ice, processes of water channels and crevasses development.

Methods and equipment. The field survey was done along the ice caps and across them to learn the glaciers' interior structure.
For the research VIY3-300 GPR(https://viy. ua/e/products/VIY3-300_Georadar.htm) with $300 \mathrm{MHz}$ antenna was used. All GPR data were recorded with GPS, with measurement deviation $0.9-1.5 \mathrm{~m}$. Data obtained with VIY3-300 GPR were processed and interpreted with Synchro and Planner software. During the processing of the data, wavelet, background removal, band pass filters and a time-dependent signal gain function were used. Data were recorded with a $330 \mathrm{~ns}$ time window. Electric permittivity 3.2 was considered for this research, according to the hyperbolic reflections inside the glaciers and according to the previous results of investigations in this area [Karušs et al., 2019]. The deepest reflections were identified at $27 \mathrm{~m}$. For the creation of thickness maps, software Surfer was used and Kriging algorithm was applied for interpolation of the data.

On each island there were recorded several profiles along and across ice caps to understand general structure of the ice caps. Directions of the profiles are marked on the thickness maps with yellow and white lines (Fig. 2, $a, 3, a, 4, a, 5)$. The number of recorded profiles was 219 , amounting to $17435 \mathrm{~m}$ in total (on Elisabethinsel there were 23 profiles $(2120 \mathrm{~m})$; Stego - 57 profiles ( $5020 \mathrm{~m}$ ); Petermann 18 profiles $(1180 \mathrm{~m})$; Berthelot -42 profiles $(2860 \mathrm{~m})$; Booth - 28 profiles $(2065 \mathrm{~m})$; Pléneau -51 profile $(4290 \mathrm{~m})$.

For this research, the data were interpreted without consideration of the earth surface topography. The information about the ice thickness and examples of the profiles along the ice cap are given in the next sections of the paper.

Objects of the research. The ice caps are located on six Antarctic Islands: Dannebrog (two islands) $\left(65^{\circ} 03^{\prime} \mathrm{S}, 64^{\circ} 08^{\prime} \mathrm{W}\right)$, Booth $\left(65^{\circ} 05^{\prime} \mathrm{S}\right.$, $\left.64^{\circ} 00^{\prime} \mathrm{W}\right)$, Pléneau $\left(65^{\circ} 06^{\prime} \mathrm{S}, 64^{\circ} 04^{\prime} \mathrm{W}\right)$, Petermann $\left(65^{\circ} 10^{\prime} \mathrm{S}, 64^{\circ} 10^{\prime} \mathrm{W}\right)$, and Berthelot Islands $\left(65^{\circ} 20^{\prime} \mathrm{S}, 64^{\circ} 09^{\prime} \mathrm{W}\right)$ (see Fig. 1).

Petermann, Dannebrog islands, Pléneau and Booth islands are relatively easy to access from the Vernadsky Station. They are located about $15-25 \mathrm{~km}$ to the North from the station along the Penola strait, and the sea ice conditions are usually beneficial for a boat trip.

It is a lot harder to get to the Berthelot Island because of the ice conditions. Often there 
is a lot of sea ice on the water and sometimes even big icebergs around the banks of the island.

Some landing sites and more broadly defined areas allow an easier access to the ice caps: on Petermann Island - the $\mathrm{N}$ and $\mathrm{W}$ beaches; on Booth — the NE bay; Pléneau the $\mathrm{N}$ and $\mathrm{E}$ beaches; for both of Dannebrogs — their NE parts; Berthelot — the N and NE parts.

Results and discussion. Ice thickness on the islands. The thickness of ice rises from the North to the South along all islands. The ice thickness probably depends on the bedrock topography and is governed by the prevailing wind direction, the same situation as on the Argentine Islands [Karuss et al., 2019]. According to the GPR survey results, in the Northern part of the islands there is a hill, which was a barrier for the snow. Bedrock topography is on the lower altitudes in Southern part of the islands and so there is a bigger ice thickness because of the bedrock topography.

Figs. 2, $a, 3, a, 4, a, 5$ show the ice thickness maps, scale for the color and in the lower part there is a small picture of the corresponding island with location of the thickness map.

Fig. 2, a shows that most of the ice cover on both of Dannebrog Islands is over $27 \mathrm{~m}$ thick. For further investigation it is better to use lower frequency antennae, such as 125 or $70 \mathrm{MHz}$, to study these objects. In the north-eastern part of both Dannebrog Islands there is a steep increase of ice thickness and ice-rock reflection is visible only on the first $200-300 \mathrm{~m}$.

On Pléneau Island the ice thickness varies from 4 to more than $27 \mathrm{~m}$. The maximum thickness is observed in the central part of the island (Fig. 3, a).

The survey on Booth and Petermann Islands was the most informative with the 300 MHz GPR antenna, because the whole depth of the ice was investigated. In the west of the Booth Island ice thickness map there is a gradual increase of ice cover up to $24 \mathrm{~m}$ in the direction of the SW edge. In the Northern, Eastern and Western parts of the map the thickness was minimal; outcrops of rocks are visible on the satellite image (Fig. $4, a$ ). On the Petermann Island, there is a gradual rise of the ice cover in the direction from the North to the South. The thinnest ice $(6 \mathrm{~m})$ is in the NE part of the territory and the thickest $\mathrm{c}$ in the SE and W parts (26 m) (Fig. 5, a).

The ice thickness map of Berthelot Island shows a steep slope of the bed-rock in the W direction, which promotes the formation of a thick ice layer $(>27 \mathrm{~m}$ ) which forms a cliff on the NE shore of the bay. In the SE part of the map, rocks are visible on the surface (Fig. 5, b).

Layering and interior anomalies. The profiles along ice caps were processed and interpreted for the investigation of the interior layering, crevasses, water-saturated or crevassed zones inside the glaciers. Directions of the profiles are marked with white lines on the thickness maps (see Fig. 2, $a-5$ ).

In the structures of all islands there are interior layers (Internal Reflection Horizons) and anomalies from interior crevasses. For each is land, the number of the layers was counted, and directions of layer counting are marked on the GPR profiles with straight tilted purple lines (Fig. 4, b, c). Top of the earth surface (snow) is shown with a dark blue line (zero level for the time and depth scales). Deeper there is a dashed blue line, which marks the border between upper snow and permafrost ice of the glacier. Ice-rock border is the deepest one and marked with a green line. Inside most of the surveyed islands there are zones with much signal scattering and some local hyperbolic anomalies(marked with yellow polygons) at the depth more than 2-5 m - these zones are interpreted to contain moisture as a result of interior melting of the ice and are called warm ice zones [Saintenoy et al., 2011].

Glaciers on the islands Elisabethinsel and Stego have similar structures. Fig. $2, b$ shows the GPR profile on the island Elisabethinsel, Fig. 2, $c$ illustrates the first 900 meters along the ice cap on Stego, and the next $800 \mathrm{~m}$ of this profile are shown on Fig. $2, d$. There are more tilted layers in the $\mathrm{N}$ parts of the islands (first $250 \mathrm{~m}$ for Elisabethinsel — red arrows on Fig. $2, b$ mark first and last tilted layers, and $400 \mathrm{~m}$ for Stego - Fig. 2, c). On further part of the ice caps (300-900 $\mathrm{m}$ for Elisabethinsel and 400 - 1700 m along Stego) layers become more elongated and stretching along the major part 

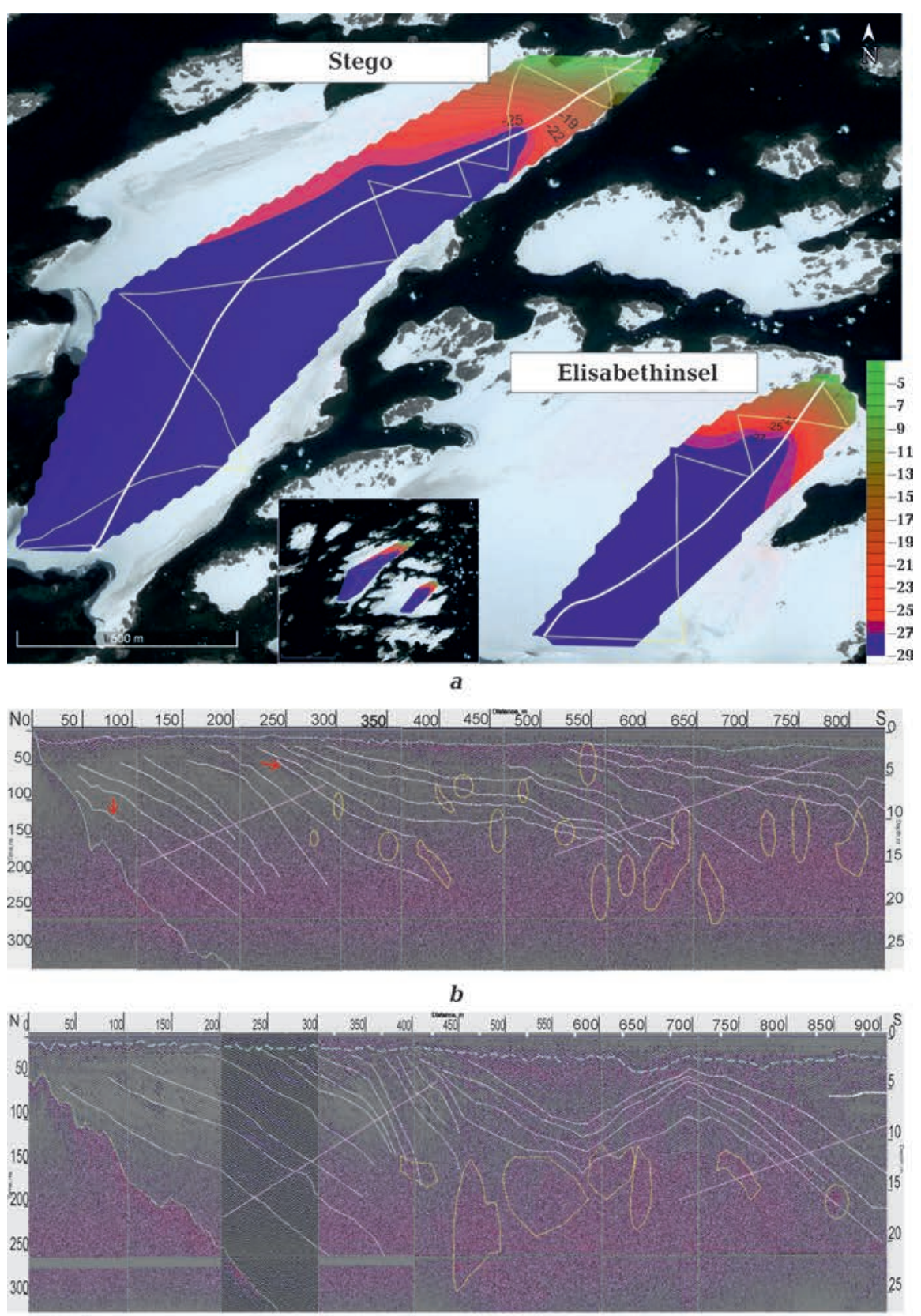

C

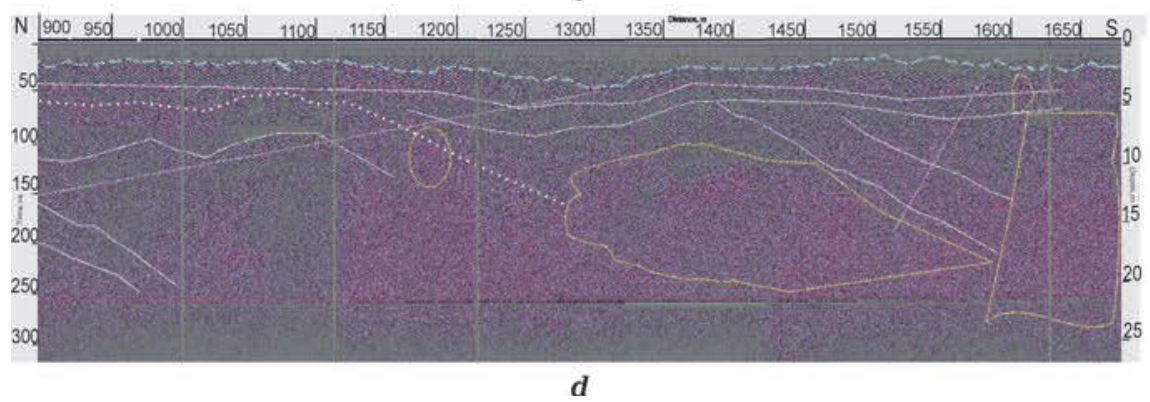

Fig. 2. Map of the ice thickness on Dannebrog islands ( $a$ ) and processed GPR profiles (along white directions) from Elisabethinsel $(b)$, along Northern part $(0-900 \mathrm{~m})$ of the profile on Stego $(c)$ and along Southern part from Stego (900-1200 m) (d): blue line - snow-ice border; white dashed lines - borders between layers; purple straight line - direction of layers counting; yellow polygons mark crevassed or water saturated zones; green dashed line — border between ice and rock. 

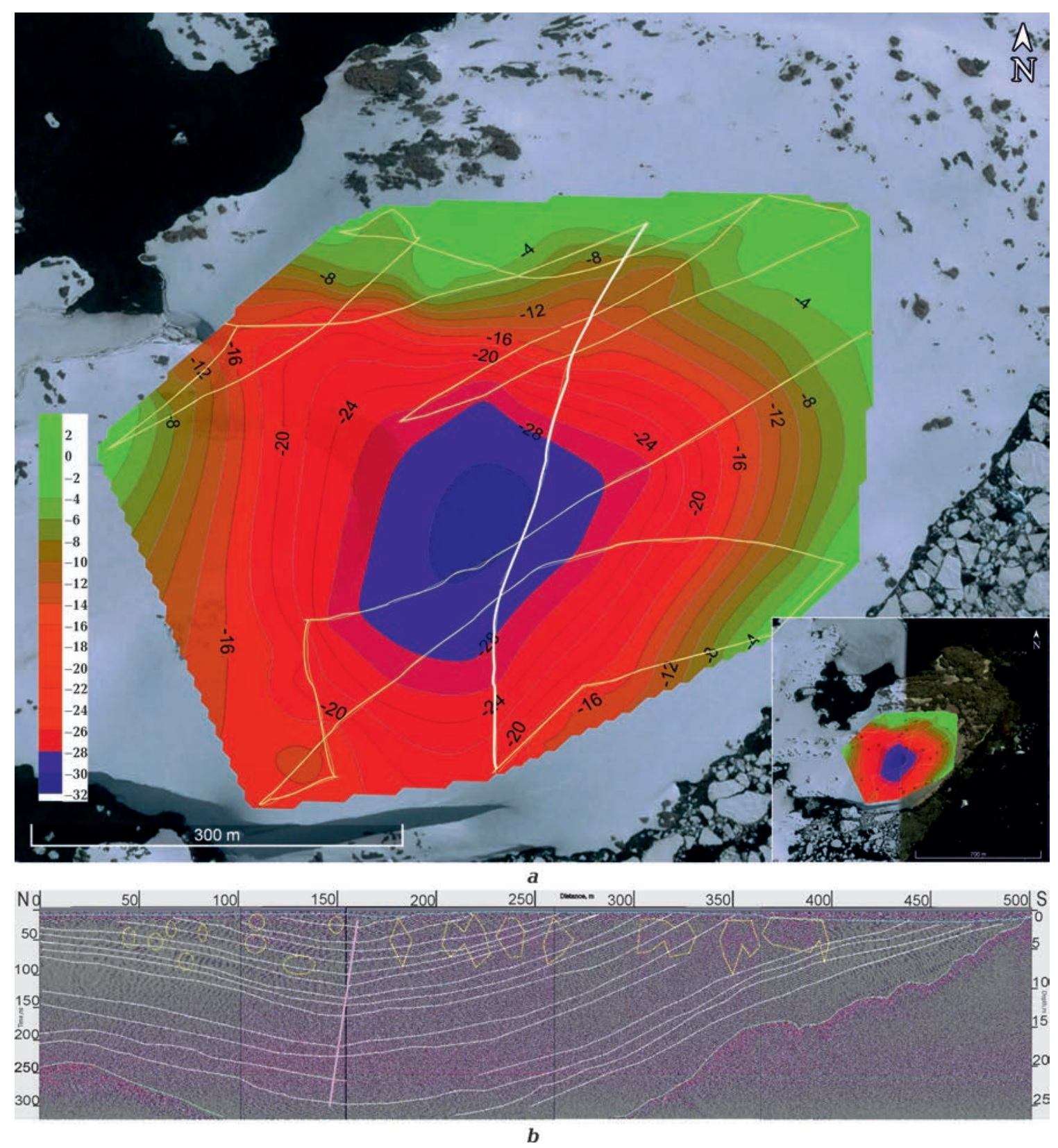

Fig. 3. Map of the ice thickness on Berthelot Island $(a)$ and processed GPR profile along the white direction on the map $(b)$.

of the glacier (Fig. $2, b-d$ ). On Elisabethinsel there are nine recognizable tilted layers (Northern part), and on Stego - 12 tilted layers. Then to the Southern part of the islands more elongated ten layers are stretching inside Elisabethinsel and the same amount in Stego. Inside the glacier on Stego, there are five more layers along the final $300 \mathrm{~m}$ ( see the most Southern part on Fig. 2, d). The border betwe- en the upper layer and the permafrost ice in the $\mathrm{N}$ part of these profiles was observed at the depth $>1 \mathrm{~m}$ along Elisabethinsel (Fig. 2, $b$ ) and at the depth 1-4 m along Stego (Fig. 2, $c)$, in the $\mathrm{S}$ part, at $2-3 \mathrm{~m}$ along Elisabethinsel (Fig. 2, b) and at 2-4.5 $\mathrm{m}$ for Stego (Fig. 2, d). Warm ice and anomalies from crevasses (yellow polygons on Fig. 2, $b-d$ ) are identified primarily deeper than $10 \mathrm{~m}$. 

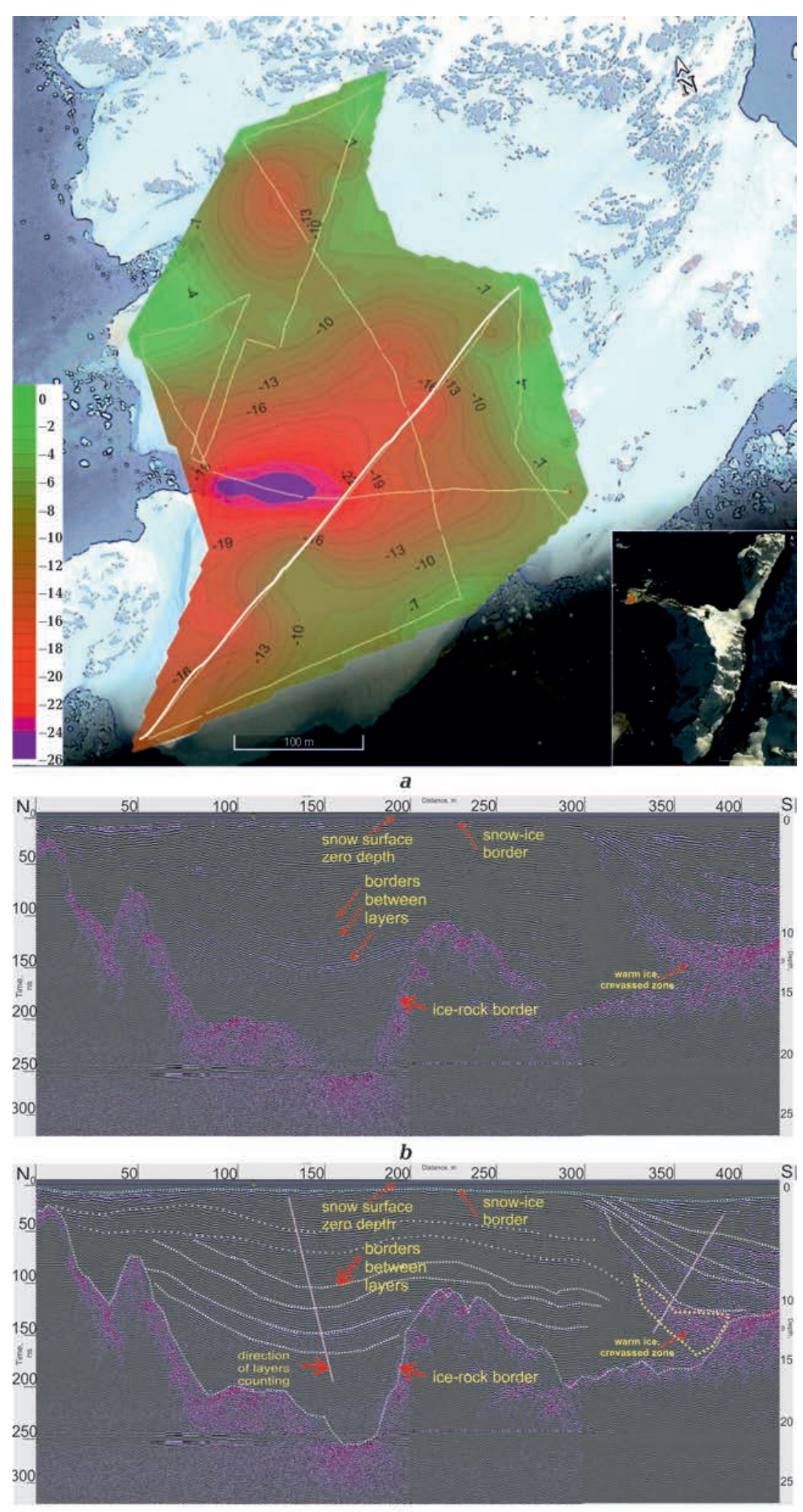

$\boldsymbol{C}$

Fig. 4. Map of the ice thickness on Booth island (a) and processed GPR profile along the white direction on ice thickness map before interpretation $(b)$ and with interpretation lines $(c)$ : blue line - snow-ice border; white dashed lines - borders between layers; purple straight line - direction of layers counting; green dashed line — border between ice and rock. 


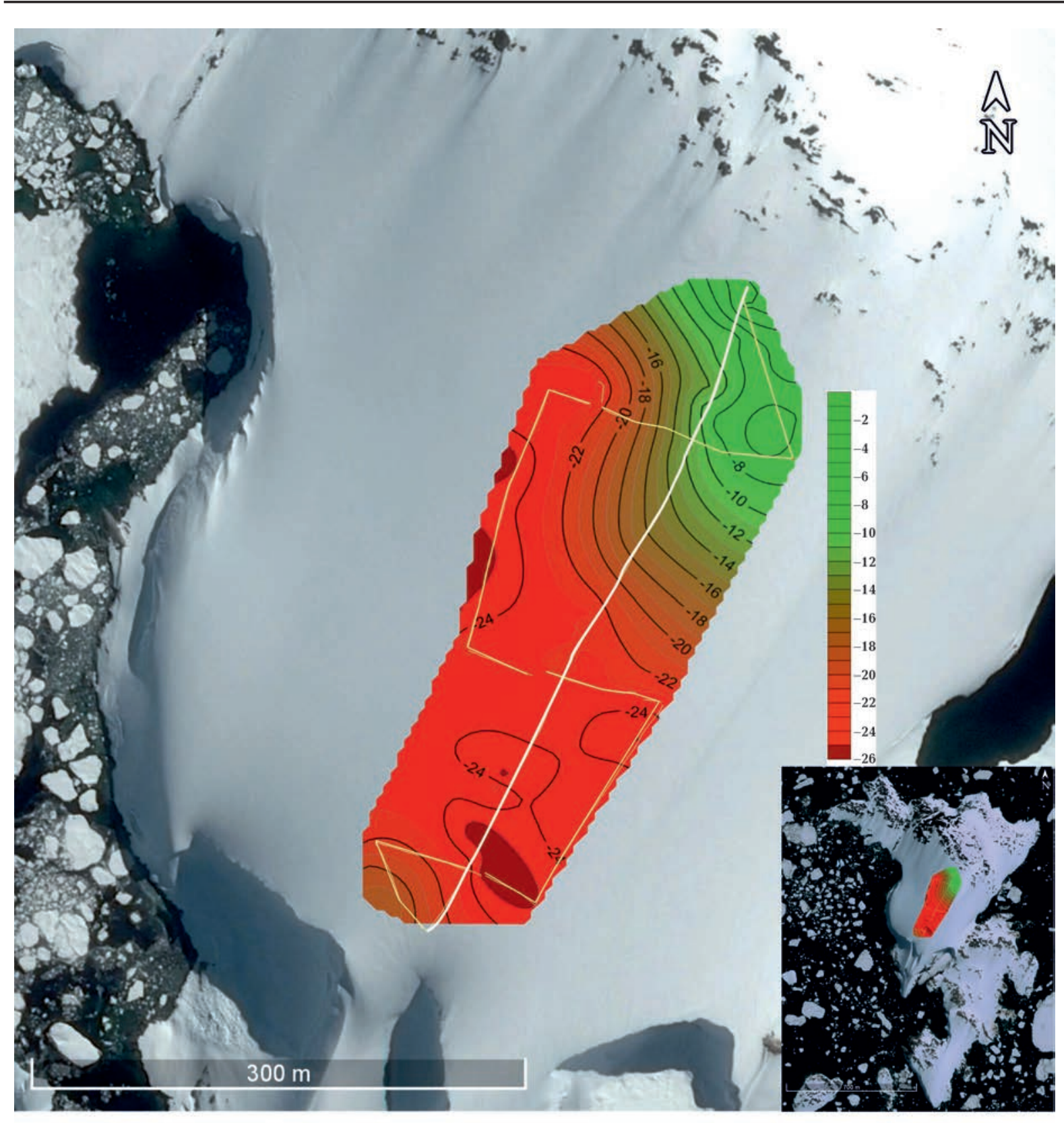

a

Fig. 5. Map of the ice thickness on Petermann (a) and Berthelot (b) islands.

Along the profile on the Pléneau Island most of the layers are stretching along the whole ice cap and there are 14 layers distinguished. Bending of the layers is visible in the central part of the island (Fig. $3, b$ ). Possibly some water can be concentrated in the deepest depressions of the Pléneau Island and lead to the creation of a lake. However, this form of the depression reflections from borders can be pro- voked by form of the snow surface above this territory. The upper snow layer is less than $2 \mathrm{~m}$ thick. There are local zones with warm ice at the depth of $1-7 \mathrm{~m}$ and deeper than $15 \mathrm{~m}$, but they are smaller than on the other islands.

There are seven layers in the $\mathrm{N}$ part of the ice cap on Booth Island and five more bent layers in the $\mathrm{S}$ part of the glacier (Fig. 4, C). The upper layer thickness is $0.5 \mathrm{~m}$ in the North and 


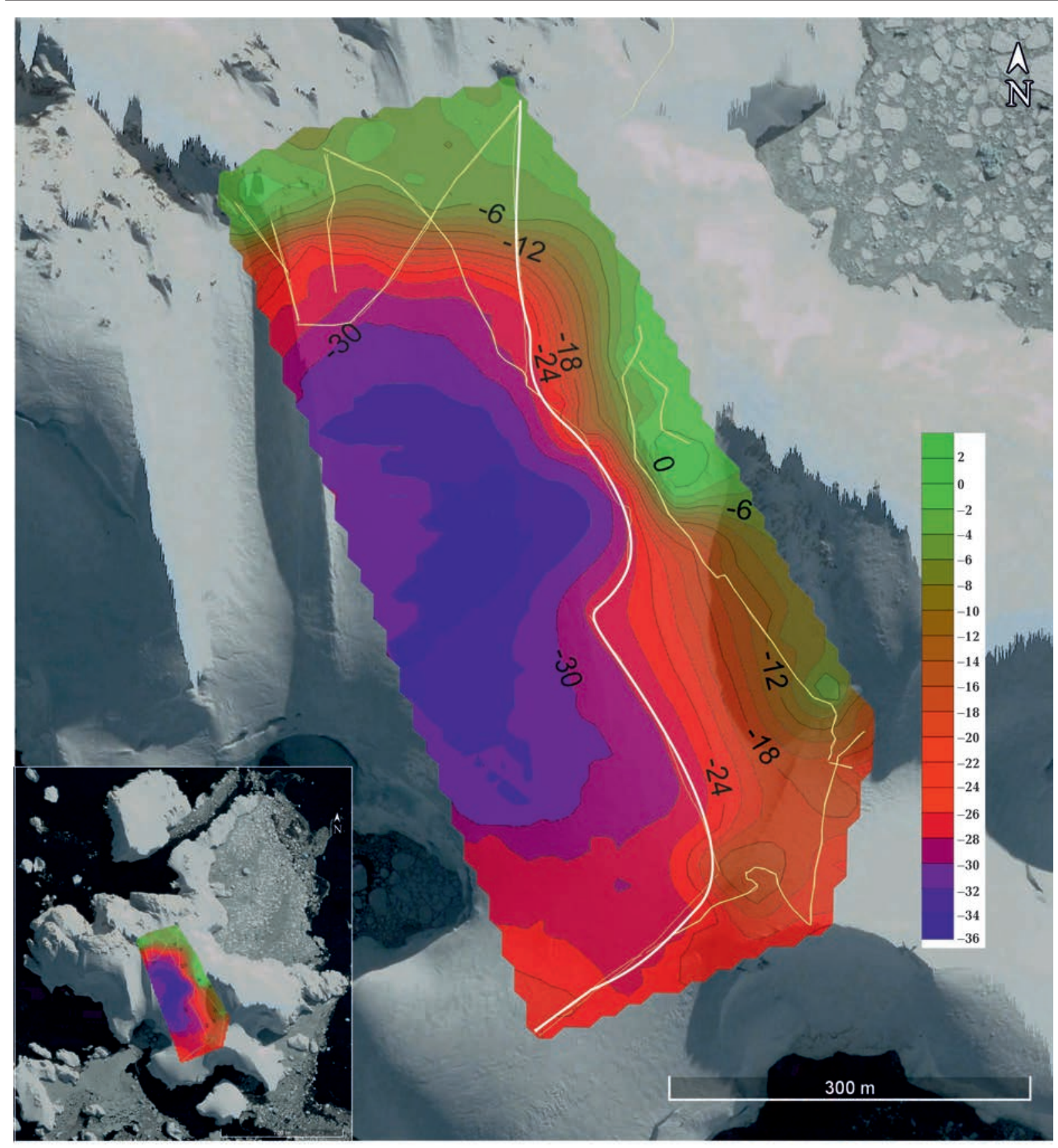

$\boldsymbol{b}$

Fig. 5 (continue).

up to $2 \mathrm{~m}$ in the South. Warm ice was visible only in the $\mathrm{S}$ part near ice-rock border at the depth of 12-13 m (Fig. 4, b, c).

The ice cap on Petermann Island contains 7 layers in the $\mathrm{N}$ part and 5 layers in the S part. The upper layer thickness varies from zero in the $\mathrm{N}$ part to $1.5 \mathrm{in}$ the $\mathrm{S}$. Zones of warm ice are observed deeper than $4 \mathrm{~m}$ in the central and $\mathrm{S}$ parts, which come together with crevassed zones (yellow polygons on Fig. 6, a).
The Berthelot Island contains seven tilted layers, slightly visible in the North, while only 1 border is traced in the Southern part, separating two layers (Fig. 6, b). There are crevassed zones and warm ice lower than $5 \mathrm{~m}$ along the most part of the ice cap. The upper part of the ice cap is thicker than on the other islands - the first reflection from the border between the upper layer and permafrost ice is observed 
at the depth of up to $5 \mathrm{~m}$ in the $\mathrm{S}$ part of the profile and $2 \mathrm{~m}$ in the $\mathrm{N}$ part. The undulating geometry of the reflection was probably created by crevasses in the ice (Fig. $6, b, 350-500$ and $650-750 \mathrm{~m}$ along the profile).

It is observed that the shape of the layers follows the bedrock topography if the ice thickness is less than $15 \mathrm{~m}$. If the ice is thicker than that, flat layers pile up on top of the layers congruent with the bedrock.

In the structures of Petermann and Dannebrog Islands layers are visible, but crevasses and warm ice zones are widely present inside the glaciers. The icecaps on Pléneau and Booth Islands are similar: layering is clearly visible, there are some crevasses at similar depths, and layers stretch along the whole ice caps. The glaciers on the Berthelot and Petermann Islands are different. The borders between la- yers do not stretch on for a long throughout the body of the glacier. The structure of the Berthelot Island contains the biggest areas of warm ice and the maximum amount of crevasses in comparison with other ice caps and a lot of crevasses are observed on the ice surface.

There are 7-14 major layers visible in ice caps' structure; each layer might have been formed in different conditions and can contain information about the climate in the past. Structure of the glaciers on the Pléneau and Booth Islands is the most homogeneous with minimum amount of crevasses and almost flat layering clearly observed. In the central part of the Pléneau Island, the ice is thicker and more layers are distinguished than on Booth.

Conclusions. The maps of ice thickness for ice caps on islands Dannebrog (2 islands), Booth, Pléneau, Petermann and Berthelot are repre-
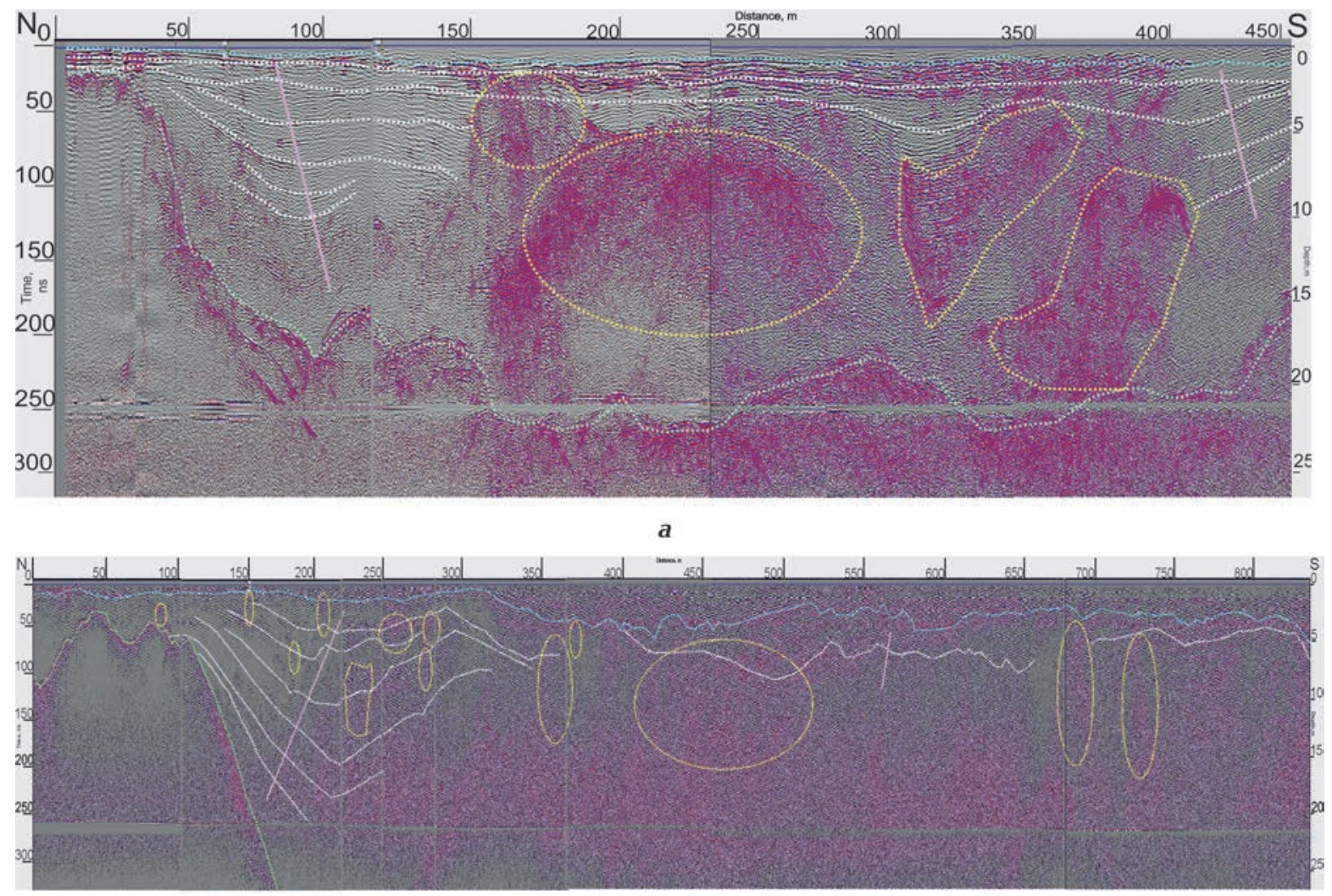

b

Fig. 6. Processed GPR profiles along Pleneau $(a)$ and along Petermann $(b)$. Directions of the survey are shown on the Fig. 3. Symbols: blue line - snow-ice border; white dashed lines — borders between layers; purple straight line — direction of layers counting; yellow polygons mark crevassed or water saturated zones; green dashed line — border between ice and rock. 
sented in the paper. General interior structure along the ice caps is shown on the GPR profiles.

Inside the ice cap on Pléneau Island, there are the biggest amount of layers - 14. Therefore, this ice cap is recommended for further in-situ investigations to take the samples from each horizon for the glaciological investigations, which can give information about glaciogeological history and paleoclimate of the region.

To calculate the area and volume of the ice caps, more precise investigations are needed, which cover the whole territory of the ice caps with exact grid of profiles. For the further more precise investigations of the islands Petermann, Booth, and the major part of Pléneau, GPR VIY3-300 (300 MHz) can be used produc-

\section{References}

Adie, R.J. (1957). The petrology of Graham Land. III. Metamorphic rocks of the Trinity peninsula series. Falkland Island Dependencies Survey Scientific reports, (20), $31 \mathrm{p}$.

Arctowski, H. (1904). Les glacesantarctiqiies (Journal d'observations relatives aux icebergsel a labanquise), Brussels, Belgian Antarctic Expedition 1897-1899.

Bakhmutov, V.G., Vaschenko, V.N., Grischenko, V.F., Korchagin, I.N., Levashov, S.P. \& Pishchanyy, Y.M. (2006). Methods and results of glaciers strength of small Wiggins (Antarctic Peninsula) and Domashniy (Galindez Island). Ukrainian Antarctic Journal, (4-5), 47-51 (in Russian).

Curtis, R. (1966). The petrology of the Graham Coast, Graham Land. British Antarctic Survey Scientific reports, (50), $70 \mathrm{p}$.

Cook, A.J., Holland, P.R., Meredith, M.P., Murray, T., Luckman, A., \& Vaughan, D.G. (2016). Ocean forcing of glacier retreat in the western Antarctic Peninsula. Science, 353, 283-286.https: //doi.org/10.1126/science.aae0017.

Chernov, A. (2017). Informativeness of ground penetrating radar method for investigations of the glaciers on Galindez, Winter and Skua islands (the Argentine islands, results for the pe- tively. However, the ice thickness on Dannebrog, Berthelot, and central part of Pléneau is more than $27 \mathrm{~m}$, so a GPR with less frequency is needed for investigation of the whole ice thickness.

A survey with the UAV is recommended to trace the crevasses before the survey on surface and to build the maps of these unexplored territories.

Acknowledgments. Research is done as a part of the Ukrainian governmental program «State Special-Purpose Research Program in Antarctica for 2011-2023». Authors are gratitude to the National Antarctic Scientific Center of Ukraine for the support of this research and the NSI Institute of Geology for access to the processing software.

riod April to November 2017). Ukrainian Antarctic Journal, 16, 29-36. https://doi.org/10.33 275/1727-7485.16.2017.56.

Chernov, A., Pishniak, D., Trokhymets, V., \& Bilyi, T. (2020a). Structure and inhabitants of the lakes and ponds on Uruguay Island(the Wilhelm Archipelago, Antarctica). Conference Proceedings, XIV International Scientific Conference "Monitoring of Geological Processes and Ecological Condition of the Environment», November 2020 (Vol. 2020, pp. 1-5). https://doi.org/ 10.3997/2214-4609.202056052.

Chernov, A., Otruba, D., Pishniak, D., Bulakh, O., Ivko, A., \& Brillinh, Y. (2020b). Layering of the ice caps on the islands Galindez, Winter, Skua (the Argentine Islands, West Antarctica). GeoTerrace-2020, 07-09 December 2020, Lviv, Ukraine. https://doi.org/10.3997/2214-4609.20205 708.

Chernov, A., Karušs, J., Lamsters, K., Krievāns, M., \& Otruba, Yu. (2018). First results of glacier monitoring on Woozle hill (Galindezisl and, the Argentine islands, Antarctica) for the period April 2017-August 2018. Monitoring of Geological Processes and Ecological Condition of the Environment, 13-16 November 2018, Kyiv, Ukraine.

Cisak, J., Milinevsky, G., Danylevsky, V., Glotov, V., 
Chizhevsky, V., \& Kovalenok, S., (2008). Atmospheric impact on GNSS observations, sea level change investigations and GPS-photogrammetry ice cap survey at Vernadsky Station in Antarctic Peninsula. In A. Capra, \& R. Dietrich (Eds.), Geodetic and geophysical observations in Antarctica (pp. 191-209). Berlin: Springer.

Fleming, W.L.S., Stephenson, A., Roberts, B.B. \& Bertram, G.C.L. (1938). Notes on the scientific work of the British Graham Land Expedition, 1934-37. The Geographical Journal, 91, 508-532.

Glotov, V.M., Kovalenok, S.V., Milinevskyy, G.P., Nakalov, E.F., \& Fulitka, Yu.V. (2003). Monitoring of small ice caps as indicators of the Antarctic Peninsula region climate change. Ukrainian Antarctic Journal, (1), 93-99 (in Russian). https://doi.org/10.33275/1727-7485.1.2003.630 (in Russian).

Gourdon, E. (1908). Géographie physique-glaciologie, pétrographie. AntarctiqueFrancaise Expedition (1903-1905).

Karušs, J., Lamsters, K., Chernov, A., Krievāns, M., \&Ješkins J. (2019). Subglacial topography and thickness of ice caps on the Argentine Islands. Antarctic Science, 31(6), 332-344. https://doi. org/10.1017/S0954102019000452.

Levashov, S.P., Yakymchuk, N.A., Usenko, V.P., Korchagin, I.N., Solovyov, V.D. \& Pishchany, Y.M. (2004). Determination of the Galindez Island ice cap thickness by the vertical electrical resonance sounding method. Ukrainian Antarc tic Journal, (2), 38-43 (in Russian).

Lüthi, D., Le Floch, M., Bereiter, B. Blunier,T., Barnola, J.-M., Siegenthaler, U., Raynaud, D., Jouzel, J., Fischer, H., Kawamura, K., \& Stocker, T.F. (2008). High-resolution carbon dioxide concentration record 650,000 - 800,000years before present. Nature, 453, 379 - 382. https://doi.org/10. 1038/nature06949.

Mitrokhin, A., Bakhmutov, V., \& Aleksieienko, A. (2018). Geology of Petermann Island (Wilhelm archipelago, westAntarctica). Visnyk Taras Shevchenko National University of Kyiv. Geology, (1), 7-15. http://doi.org/10.17721/1728-2713. 80.01 (in Ukrainian).
Rau, F., Mauz, F., DeAngelis, H., Jaña, R., Neto, J.A., Skvarca, P., Vogt, S., Saurer, H., \& Gossmann, H. (2004). Variations of glacier frontal positions on the northern Antarctic Peninsula. Annals of Glaciology, 39, 525-530. https://doi.org/10.3189/1 72756404781814212 .

Rundle, A.S. (1973). Glaciology of the Marr Ice Piedmont, Anvers Island, Antarctica. Institute of Polar Studies Report No. 47. Columbus, OH: Research Foundation and the Institute of Polar Studies. The Ohio State University, 237 p. Sadler, I. (1968). Observations on the ice caps of Galindez and Skua islands, Argentina Islands, 1960 -66. British Antarctic Survey Bulletin, (17), $21-49$.

Saintenoy, A., Friedt, J.-M., Tolle, F., Bernard, E., Laffly, D., Marlin, C., \& Griselin, M. (2011). High density coverage investigation of the Austre Lovén Breen (Svalbard) using Ground Penetrating Radar. 6th International Workshop on Advanced Ground Penetrating Radar, Jun 2011, Aachen, Germany. Retrieved from https://hal. archives-ouvertes.fr/hal-00864530.

Siegert, M.J., Hodgkins, R., \& Dowdeswell, J.A. (1998). A chronology for the Dome C deep ice core site through radio-echo layer correlation with the Vostok ice core, Antarctica. Geophysical Research Letters, 25(7), 1019-1022. https:// doi.org/10.1029/98GL00718.

Smith, A.M., Vaughan, D.G., Doake, C.S.M., \& Johnson, A.C. (1998). Surface lowering of the ice ramp at Rothera Point, Antarctic Peninsula, in response to regional climate change. Annals of Glaciology, 27, 113-118. https://doi.org/10. 3189/1998AoG27-1-113-118.

Stewart, J. (2011). Antarctica: an encyclopedia. 2nd ed. Vol. 1 McFarland \& Company, Inc., Publishers Jefferson, North Carolina, and London.

Thomas, R.H. (1963). Studies on the ice cap of Galindez Island, Argentina Islands. British Antarctic Survey Bulletin, (2), 27-43.

Tretyak, K., Glotov, V., Golubinka, Y. \& Marusazh, K. (2016). Complex geodetic research in Ukrainian Antarctic station 'Academician Vernadsky' (years 2002 - 2005, 2013 - 2014). Reports on Geodesy and Geoinformatics, (100), 149-163 (in Russian). 


\title{
Розвідувальне георадарне дослідження крижаних шапок на островах Архіпелагу Вільгельма і острова Бертело (Західна Антарктида)
}

\author{
А. Чернов ${ }^{1}$, А. Івко ${ }^{2}$, О. Булах ${ }^{2}, 2021$ \\ ${ }^{1}$ Національний антарктичний науковий центр України, Київ, Україна \\ ${ }^{2}$ Інститут геології Київського національного університету імені Тараса Шевченка, \\ Київ, Україна
}

\begin{abstract}
Наведено результати георадарних досліджень льодовиків на антарктичних островах. Малі льодовики на островах західного узбережжя Антарктичного півострова досліджували рідко. Товщина льоду - важливий параметр для розрахунку об'єму льодовиків та відповідно, їх впливу на рівень Світового океану. Вивчення будови льоду дають можливість вилучити інформацію про минулі кліматичні епохи та зрозуміти гляціогеологічну історію регіону. Однак сучасна база даних Global Terrestrial Network for Glaciers не містить інформації про товщину та внутрішню структуру розглянутих у статті льодових шапок. Мета дослідження - вивчення товщини льоду і його внутрішньої будови на антарктичних островах Плено, Пітерманн, Бус, Барселот, Стего і Елізабетінзель, отримання інформації про загальну будову покривних шапок і товщину льоду. Цю територію описано лише на рівні оглядових досліджень на межі XIX-XX ст. Аля запису даних застосовано наземний георадар (GPR) VIY 3-300 (300 МГц). Оброблені профілі GPR відображають до 14 шарів (о-в Плено) всередині крижаних шапок. Наявні внутрішні тріщини, зони концентрації вологи і каверн. Побудовано карти товщин льоду для кожного острова. Товщина льоду на островах Ааннеброг (група островів), Бус і частині о-ва Плено становить більш як 27 м, тому рекомендовано використовувати антени з частотою, меншою за 300 МГц для більш глибокого і детального дослідження на цих островах. На острівних льодовиках є тріщини біля поверхні, тому для майбутніх досліджень рекомендовано використовувати спеціальне обладнання (мотузки, шоломи, льодоруби, кішки і т. ін.) для вирішення надзвичайних ситуацій. Вказано місця для найзручнішої висадки на островах.
\end{abstract}

Ключові слова: љьодові шапки, льодовики, Антарктида, георадар, внутрішня будова.

\section{Разведывательные георадарные исследования ледяных шапок на островах Архипелага Вильгельма и острова Бертело (Западная Антарктида)}

\author{
А. Чернов ${ }^{1}$, А. Ивко ${ }^{2}$, О. Булах ${ }^{2}, 2021$ \\ ${ }^{1}$ Национальный антарктический научный центр Украины, Киев, Украина \\ ${ }^{2}$ Институт геологии Киевского национального университета имени Тараса Шевченко, \\ Киев, Украина
}

В статье представлены результаты исследований островных ледников Западной Антарктиды. Региональные гляциогеологические исследования малых ледников на островах западного побережья Антарктического полуострова проводятся редко. Толщина ледников - важный параметр для расчета массы ледников и их влияния на уровень Мирового океана. Изучение структуры льда помогают получить информацию о прошлых климатических эпохах и понять гляциогеологическую историю 
региона. Однако глобальная база данных Terrestrial Network for Glaciers не содержит информации о толщине и внутреннем строении ледяных шапок, представленных в статье. Цель работы - изучение толщины льда и его внутренней структуры на антарктических островах Плено, Питерманн, Бус, Барселот, Стего и Элизабетинзель, обзорные исследования строения ледяных шапок и толщины льда. Этот район был посредственно описан в экспедиционных отчетах первопроходцев 19-20 вв. В результате исследований во внутренней структуре ледников обнаружены трещины, зоны концентрации влаги и пустоты. Прослеживается слоистость льда, в структуре ледника на о-ве Плено выявлено максимальное количество слоев - 14. Аля каждого рассмотренного острова построена карта толщины льда. Мощность льда на островах Ааннеброг (группа островов), Бус и части о-ва Плено составляет более 27 м, поэтому рекомендуется использовать антенну частотой менее 300 МГц Аля более глубокого и детального изучения ледников. В целях соблюдения правил безопасности для дальнейших исследований островных ледников рекомендуется использование специального страховочного оборудования (веревки, ледорубы, кошки, карабины и др.). В тексте указаны места для более удобной высадки на островах.

Ключевые слова: островные ледники, ледники, Антарктида, георадар, внутреннее строение. 